\title{
Energy Consumption and Economic Development in Sub-Saharan African Countries: Role of Governance Quality
}

\author{
Hermann Clachel Lekana \\ Faculty of Economic Sciences, Marien Ngouabi University, Brazzaville, Republic of the Congo \\ Email: hermann.lekana@umng.cg
}

How to cite this paper: Lekana, H. C. (2020). Energy Consumption and Economic Development in Sub-Saharan African Countries: Role of Governance Quality. Modern Economy, 11, 1901-1918.

https://doi.org/10.4236/me.2020.1111127

Received: September 21, 2020

Accepted: November 21, 2020

Published: November 24, 2020

Copyright ( 2020 by author(s) and Scientific Research Publishing Inc. This work is licensed under the Creative Commons Attribution International License (CC BY 4.0).

http://creativecommons.org/licenses/by/4.0/

\begin{abstract}
The objective of this paper is to analyze the role of governance quality on the relationship between economic growth and energy consumption in a panel of twenty (20) sub-Saharan African (SSA) countries over a period from 1996 to 2017. Techniques such as the generalized method of moments (GMM) in dynamics and the Granger test were utilized. The results of the estimations show that energy consumption is an essential factor in the economic growth of SSA countries and that the quality of governance is a catalyst of this relationship. The policy implications of these results are elaborated.
\end{abstract}

\section{Keywords}

Energy Consumption, Economic Growth, Governance, Sub-Saharan Africa

\section{Introduction}

The relationship between energy consumption and economic development is so inextricable that the level of global energy consumption is growing, and the correlation that seems to exist between the richest countries and the world's largest energy consumers is more prevalent. It is in this context that the United Nations Development Programme (UNDP, 2015) maintains that the production and distribution of energy is considered to be an indispensable factor for economic and sustainable development.

Consequently, the literature linking economic performance and energy consumption can be divided based on two approaches that are employed: the orthodox approach and the heterodox approach. The orthodox approach does not consider the existence of a relationship between economic performance and energy consumption, and if there is a relationship, economic performance ex- 
plains energy consumption. On the other hand, the heterodox approach argues that there is a two-way relationship between energy consumption and economic performance. If this relationship is unidirectional, then causality is generated from energy consumption to economic performance.

Despite this theoretical controversy, it is difficult to prove this relationship exists in empirical works. Indeed, since the seminal work of Kraft \& Kraft (1978), there has been a divergence of results that can be grouped based on four factors (growth, conservation, neutrality and feedback). Percebois \& Hansen (2011) show that the relationship is caused by the economic structure or by changes in the behavior of economic actors. In Kilishi et al. (2013), this divergence is due to the failure to take institutional issues into account in this relationship. According to the latter, only institutional quality can explain the poor economic performance of sub-Saharan Africa since conventional neoclassical growth models have failed. Thus, institutional quality has an important effect on economic performance.

Economic performance is affected by several economic factors (Simon, 2010). This work considers the gross domestic product. Although this factor is considered to be insufficient, it remains the main indicator with the double advantage, as mentioned by Simon (2010). For this author, the first advantage of GDP is that it fits into the internationally standardized accounting and statistical framework, and the second advantage is that it is a synthetic concept that is widely recognized and used. Over the period 2000-2012, energy demand in sub-Saharan Africa increased by nearly $45 \%$ and increased by the same level in 2013, according to economic growth data for 2013 (International Energy Agency: IEA, 2014). However, in 2017, out of thirty-three countries in SSA, only two reported a level above the world average (Sobrinho \& Thakoor, 2019). Thus, observation of the level of economic performance of sub-Saharan African (SSA) countries shows that the GDP seems to be evolving in the same direction as the level of energy consumption. However, institutional quality indices evolve in the opposite direction.

Several studies, such as Lékana (2018b), show that energy consumption and economic growth are not related. These results can be explained by the lack of institutional variables in these studies. Thus, the central question of this paper can be formulated as follows: What is the role of governance in the relationship between energy consumption and economic performance in SSA countries? The objective of this paper is to analyze the role of governance in the relationship between economic growth and energy consumption in SSA countries.

This work is organized as follows. After the introductory section, the second section focuses on the evolution of governance indicators, energy consumption and economic growth in SSA countries. The third and fourth sections provide the literature review and methodology, respectively. The presentation and interpretation of the results, followed by the conclusion and policy implications, are provided in sections five and six, respectively. 


\section{Literature Review}

The literature on the role of governance in the relationship between economic growth and energy consumption is controversial. Indeed, according to the literature on the relationship between energy consumption and economic growth there are two opposing approaches. On the one hand we have the orthodox approach, which refutes the contribution of energy consumption to economic growth and supports two hypotheses (the growth hypothesis and the neutrality hypothesis). On the other hand, the heterodox approach, which admits the existence of a link between energy consumption and economic growth. They are based on two hypotheses (the conservation hypothesis and the feelback hypothesis).

Regarding the first approach, energy does not influence economic growth and if there is a link, it is rather economic growth that influences energy consumption. To support their point, they rely on theories of economic growth (traditional and endogenous). According to proponents of this approach (Stiglitz, 1974; Lucas, 1988; Barro, 1990; Mankiw et al., 1992), energy is not an explanatory factor for growth. For heterodox economists, who rely on biophysical theory and the principles of thermodynamics, energy is considered an indispensable and sometimes the most important factor in explaining economic growth (Lékana, 2018a; Percebois \& Hansen, 2011; Kane, 2009; Jumbe, 2004). In summary, for heterodox species, any transformation of matter requires any amount of energy. These controversies have been the subject of several attempts to explain them (Percebois \& Hansen, 2011; Stern, 2012; Lékana, 2018a).

However, since the work of North (1990), several authors have attempted to explain the limitations of orthodox analysis (Hall \& Jones, 1999; Acemoglu et al., 2001; Acemoglu et al., 2008; Kilishi et al., 2013). In this regard, Kilishi et al. (2013) argue that it seems difficult, if not impossible, to discuss the factors of economic growth without considering the quality of governance. Acemoglu et al. (2008) argue that institutions are the fundamental causes of growth while capital stocks (physical and human), technology and energy are only intermediate factors. Knowing that the relationship between economic growth and energy consumption is often indexed for its polluting nature, van der Bergh (2001), emphasizes that only institutions can harmonize this relationship so that it benefits future generations. For his part, Mundial (2001), argues that a strong institution is crucial for economic development, as it helps to minimize market imperfections. Economies with strong and developed institutions are able to implement effective and efficient regulations that contribute to economic development. Conversely, weak institutions have a low regulatory capacity and thus can hinder a country's economic growth.

Empirically, the literature can be separated into two groups: in the first, papers that did not integrate institutional quality and in the second, those that did take institutional quality into account.

With regard to the first group, since the seminal work of Kraft \& Kraft (1978) 
on the United States, several papers have emerged, for example, Saidi et al. (2018). In their paper, they study the existence of asymmetric effects in the energy-growth relationship using data on the per capita real GDP and per capita energy consumption over the period 1971-2008 in 12 African countries. The estimation results show that for Gabon, Nigeria and Côte d'Ivoire, the growth rate could be negatively affected by conservation policies. For Benin, Kenya and Sudan, conservation policies could improve growth.

Streimikiene \& Kasperowicz (2016) examine the long-term relationship between energy consumption and economic growth in eighteen European Union countries over the period 1995-2012 and show that energy consumption and economic growth have a positive relationship.

Bhattacharya \& Bhattacharya (2014) examine the causal link between energy consumption (i.e., electricity, coal and oil) and economic growth in India and China during the period 1980-2010 and the estimation results show that for India, there is a two-way relationship between coal consumption and economic growth, while for oil, they find a one-way relationship from economic growth to oil consumption. In the case of China, they find that there is a unidirectional relationship from oil consumption to economic growth and from coal consumption to economic growth.

Regarding the second group; Emmanuel \& Ebi (2013) examined the relationship between institutional quality, oil resources and economic growth in Nigeria, Brazil and Canada between 2000 and 2010 using a difference-of-difference approach. The study found that there were differences in the rate of economic growth between Nigeria and Canada on the one hand and Nigeria and Brazil on the other, and that these differences in the observed rate of economic growth between the two is due to differences in the level of corruption between the countries. In addition, it was observed that there is a two-way causality between differences in the level of corruption and differences in the level of government effectiveness. Edame \& Okoi (2015) will assess the effect of energy consumption and institutional quality on the performance of the manufacturing sector in $\mathrm{Ni}$ geria between 1999 and 2013 using the ordinary least squares technique. The study used three measures of institutional quality: the Economic Freedom Index, the Corruption Perception Index, and the Monetary Intensive Contract Index. On the other hand, industrial sector electricity consumption (SLC), total gas consumption (GCS) and total oil consumption (PCN) were used as indicators of energy consumption. The results of the study show that the industrial sector's consumption of electricity, oil and gas does not have a significant impact on the performance of the manufacturing sector. The results also indicated that the level of perception of corruption has a significant effect on the performance of the manufacturing sector. As for Bass (2019) in the Russian framework, assessing the impact of institutional quality and world oil prices on Russian manufacturing performance, based on data for the period 1996-2017. After using Granger's causality technique the results show that oil prices, institutional quality and economic growth in Russia are co-integrated in the long run. However, the 
short-term effects are statistically insignificant. The results of the Granger causality test show unidirectional causality from oil prices and institutional quality to economic growth.

For Ogundipe et al. (2016) in their study examining the relationship between electricity consumption and economic development using an extended neoclassical model for the period 1970-2013. The study incorporates the uniqueness of the Nigerian economy by controlling for the role of institutions, technology, emissions and economic structure in the electricity consumption-development argument. The study revealed the existence of a long-term cointegration equation with electricity consumption inversely related to economic development. Similarly, the vector error correction model failed to reject the null hypothesis of long-term non-convergence. Finally, the study found evidence supporting the existence of a unidirectional relationship from economic development to electricity consumption.

Adams et al. (2016) examined the relationship between energy consumption and economic growth and the role of democracy in sixteen sub-Saharan African countries over the period 1971 to 2013. They use two approaches, the vector autoregressive panel (PVAR) and the generalized method of moments. They show that, initially, energy consumption and economic growth have a two-way relationship. In the second, the interaction variable (energy consumption and democracy) positively impacts economic growth.

We note that, initially, whether in developed or developing countries, the results remain mixed, which justifies the relevance of this paper. Secondly, we note that few papers seem to question the consideration of the role of governance in the relationship between energy consumption and economic growth.

\section{Methodology and Data}

In this section, we first present the methodology for assessing the effects of governance quality on the relationship between energy consumption and economic growth, then the data and their sources.

\subsection{Model for Assessing the Effects of Governance Quality on the Relationship between Energy Consumption and Economic Growth}

The objective of this paper is to analyze the role of institutional quality on the relationship between economic growth and energy consumption in sub-Saharan African countries. To do so, we draw inspiration from the growth model proposed by Lékana (2018a). The author uses an augmented growth model by Stigliz (1974) with the inclusion of natural factors.

$$
Y_{i t}=A_{i t} K_{i t}^{\alpha} L_{i t}^{\beta} R_{i t}^{\gamma}
$$

where $Y_{i t}, K_{i t}, L_{i t}$ and $R_{i t}$ represent the real GDP, physical capital stock, total labor force, and resource factor stock, respectively. $i$ corresponds to the number of countries in sub-Saharan Africa, and $t$ represents the year (1996 to 
2017); $\alpha, \beta$, and $\gamma$ refer directly to returns to scale. According to Shafiei et al. (2013), the literature on growth models has evolved to include energy as a natural factor of growth.

$$
Y_{i t}=A_{i t} K_{i t}^{\alpha} L_{i t}^{\beta} E_{i t}^{\gamma}
$$

with $E_{i t}$, the energy consumption and other variables remaining unchanged.

For those who hold the endogenous view of economic growth, apart from the traditional factors, there are others that can contribute and are rooted in the endogenous nature of technical progress. Thus, we have:

$$
A_{i t}=f\left(\text { ouv }_{i t}, \text { institution }_{i t}\right)=A_{0} \mathrm{e}^{\theta_{i} Z_{i t}}
$$

ouv is a measure of commercial and institutional openness and thus the quality of governance. Substituting $A$ by its equation, Equation (2) becomes:

$$
Y_{i t}=A_{0} e^{\theta_{i} z_{i t}} K_{i t}^{\alpha} h_{i t}^{\beta} E_{i t}^{\gamma}
$$

After linearizing Equation (4), we obtain the model for estimation purposes as follows

$$
\ln Y_{i t}=\ln A_{0}+\alpha \ln K_{i t}+\beta \ln h_{i t}+\gamma \ln E_{i t}+\delta \text { institution }_{i t}+\rho \ln \operatorname{ouv}_{i t}+\varepsilon_{i t}
$$

To better capture the fact that governance conditions the effect of energy consumption on economic growth, we introduce an interaction variable between these two variables: a variable representing the interaction between energy consumption and the institution. Equation (5) transforms to Equation (6), which is: $\ln Y_{i t}=\ln A_{0}+\alpha \ln K_{i t}+\beta \ln h_{i t}+\gamma \ln E_{i t}+\delta$ institution $_{i t}+\delta \gamma \ln E_{i t}$ institution $_{i t}+\varepsilon_{i t}$

From Equation (6), we can determine the marginal effect of energy consumption on economic growth, which depends on the quality of governance

$$
\frac{\delta \ln Y_{i t}}{\delta \ln E_{i t}}=\gamma+\delta \gamma \text { institution }_{i t}
$$

Since the quality of governance is expected to improve the marginal effect of energy consumption on economic growth, the coefficient should be strictly positive. In addition, the existence of a nonlinear effect is tested by examining the sign and significance of the interaction coefficient $\delta \gamma$. Thus:

- If $\gamma$ and $\delta \gamma$ are positive (negative) then energy consumption has a positive (negative) effect on economic growth and governance favorably affects (aggravates) this impact.

- If $\gamma>0$ and $\delta \gamma<0$, then energy consumption has a positive impact on economic growth, but governance reduces this impact.

- If $\gamma<0$ and $\delta \gamma>0$, then energy consumption has a negative impact on economic growth, but governance in this case plays a mitigating role.

\subsection{Sources and Presentation of the Data}

The data used in this paper to capture the effects of governance in the relationship between energy consumption and economic development covers 20 sub-Saharan African countries and extends over a period from 1996 to 2017. The data are 
taken from the World Bank, specifically from the world development indicators (WDI) database for economic variables and in world governance indicators (WGI) database for governance data. This range is dictated by the availability of governance data.

The dependent variable selected is real gross domestic product, which explains economic performance in SSA countries. It is measured in US dollars. Energy consumption is captured by the variable energy use in kilograms of oil equivalent, which is calculated by the World Bank by aggregating all energy uses regardless of source. The expected sign is positive in accordance with Stern's (2012) work.

Real gross fixed capital formation is the variable that captures the investments made in a country. Human capital is approximated by the gross primary school enrolment ratio. The capacity of these countries to trade with the outside world is captured by trade openness. In order to assess the quality of governance in this model, the indicators proposed by the World Bank have been used (Kaufmann et al., 1999). However, without being exhaustive on its composition, they include: control of corruption, government effectiveness, political stability, regulatory control, the role of the rule of law and freedom of expression. The indicators are assessed over a range of approximately -2.5 to 2.5 . The closer a country is to 2.5 , the better off it is and vice versa. We proceeded by creating a composite variable obtained by averaging the governance indicators in accordance with the work of (Kouika et al., 2018; Batila, 2018; Loubelo, 2018; Okiemy, 2018).

The interaction variable mobilized in this work is the product of the quality of institutions and energy consumption as proposed by Adams et al. (2016). Thus, the interaction variable is the product between the institution variable and energy consumption. For this study, it is expected that this variable will have a positive sign.

The variables are summarized in Table 1.

\section{Presentation and Interpretation of the Results}

In this section, we will first present the results and then their interpretation.

Table 1. Variables and their expected sign.

\begin{tabular}{|c|c|c|c|}
\hline Variables & Definition & Sign & $\begin{array}{l}\text { Data Source } \\
\text { of Variables }\end{array}$ \\
\hline$Y$ & Constant basic gross domestic product 2010 & & \\
\hline FBCF & Gross fixed capital formation in \%GDP & + & \\
\hline$H$ & Gross primary school enrollment rate & + & \\
\hline Ouv & Open trade openness as a percentage of GDP & + & $\begin{array}{c}\text { Word Bank } \\
\text { (2009) }\end{array}$ \\
\hline$E$ & Energy use in Kep & & \\
\hline Institution & Average of the governance variables & & \\
\hline Interaction & Interaction institution ${ }^{\star}$ energy consumption & + & \\
\hline
\end{tabular}

Source: Created by the author based on the prior literature. 


\subsection{The Presentation of the Results}

To capture the effects of the quality of institutions on the relationship between economic growth and energy consumption, we use dynamic panel estimation. Thus, generalized method of moments will be retained. To determine the nature of the relationship between these variables, PVAR seems to be an appropriate method that will allow us to use the Granger panel approach. Stationarity and cointegration tests are used to avoid spurious relationship problems. However, we will start by presenting the characteristics of the central and dispersion tendencies of our variables.

\subsubsection{Descriptive Statistics}

The presentation of the results requires, first, a descriptive analysis of the variables. This description is done using the central tendency and dispersion characteristics that are summarized in Table 2 .

With regard to gross fixed capital formation, in the twenty (20) countries of sub-Saharan Africa over a period of sixteen (16) years, we note that on the whole, its average is equal to 22.03358 as a percentage of GDP. Its interindividual variance

Table 2. Descriptive statistics.

\begin{tabular}{|c|c|c|c|c|c|c|}
\hline Variables & & Average & $\begin{array}{l}\text { Standard } \\
\text { deviation }\end{array}$ & Minimum & Maximum & Observations \\
\hline \multirow[t]{3}{*}{ FBCF } & overall & 22.03358 & 7.291778 & 2.00044 & 43.0513 & $N=320$ \\
\hline & between & & 5.429936 & 8.979212 & 30.54056 & $n=20$ \\
\hline & within & & 5.007218 & 6.830288 & 43.129 & $T=16$ \\
\hline \multirow{3}{*}{ PIB } & overall & $3.92 \mathrm{e}+10$ & $7.59 e+10$ & $2.50 \mathrm{e}+09$ & $4.60 \mathrm{e}+11$ & $N=320$ \\
\hline & between & & $7.47 e+10$ & $3.55 e+09$ & $3.46 \mathrm{e}+11$ & $n=20$ \\
\hline & within & & $2.10 \mathrm{e}+10$ & $-9.71 e+10$ & $1.53 \mathrm{e}+11$ & $T=16$ \\
\hline \multirow[t]{3}{*}{ Ouv } & overall & 74.99471 & 29.40929 & 19.1008 & 165.6459 & $N=320$ \\
\hline & between & & 27.54165 & 32.47962 & 142.4272 & $n=20$ \\
\hline & within & & 11.91773 & 33.72425 & 112.9092 & $T=16$ \\
\hline \multirow{3}{*}{$\begin{array}{c}\text { Consumption } \\
\text { of energy }\end{array}$} & overall & 603.819 & 491.7907 & 113.423 & 3098.42 & $N=320$ \\
\hline & between & & 490.9673 & 134.6904 & 2422.499 & $n=20$ \\
\hline & within & & 110.1991 & -346.4304 & 1279.74 & $T=16$ \\
\hline \multirow[t]{3}{*}{ Tbsp } & overall & 99.21079 & 19.50393 & 39.51496 & 142.48 & $N=320$ \\
\hline & between & & 17.96243 & 59.33554 & 140.0385 & $n=20$ \\
\hline & within & & 8.53966 & 71.23118 & 122.7298 & $T=16$ \\
\hline \multirow[t]{3}{*}{ Institution } & overall & -0.6852086 & 0.597305 & -1.929355 & .879893 & $N=320$ \\
\hline & between & & 0.5751542 & -1.579218 & .6072743 & $n=20$ \\
\hline & within & & 0.203779 & -2.184983 & .3163353 & $T=16$ \\
\hline \multirow[t]{3}{*}{ Interation } & overall & -4.196774 & 3.750518 & -11.23675 & 6.09488 & $N=320$ \\
\hline & between & & 3.61317 & -9.427443 & 4.230923 & $n=20$ \\
\hline & within & & 1.274857 & -14.76376 & 1.736558 & $T=16$ \\
\hline
\end{tabular}

Source: Created by the author using data extracted from the WDI and GID. 
(Between) is equal to 5.429936, while the intraindividual variance (within) is 5.007218. Its total variance is higher than the other two, with a value of 7.291778, which suggests that gross fixed capital formation in the different countries is heterogeneous. When considering the other variables, the same heterogeneous behavior can also be observed; total variance is higher than the other variances, and the interindividual variance is also higher than the intraindividual variance.

Apart from the variances, overall, we note that the gross domestic product, openness, institutional quality, energy consumption, the gross primary school enrollment rate, and the interaction have averages equal to $3.92 \mathrm{E}+10,74.99471$, $-1.274339,603.819,99.21079$ and -7.827351 , respectively.

Overall, the difference between the minimum and maximum is very large across the whole when considering the means of the variables, which suggests a strong dispersion between countries.

\subsubsection{Stationarity Tests}

The use of the unit root in panel data has evolved dramatically in a short period of time. Currently, there are several types tests that can generate the unit root. The first-generation tests allow for the existence of an independent cross-sectional unit (Maddala \& Wu, 1999; Choi, 2001; Levin et al., 2002; Breitung, 2000; Hadri, 2000). The second-generation tests allow for the existence of a dependent cross-sectional unit (Pesaran, 2004; Moon \& Perron, 2004; Bai \& Ng, 2004).

In this paper, we perform four unit root tests. The first two are first-generation tests, which are the tests proposed by Levin, Lin, \& Chu (2002), where only the constant is assumed to be heterogeneous, and Im, Peasaran, \& Shin (2003), where the autoregressive root is assumed to be heterogeneous. The second two are second-generation tests that make it possible to consider dependence between individuals: Choi's test (2002) and Pesaran's test (2004).

The results of the stationarity tests are presented in Table 3.

Table 3. Stationarity test.

\begin{tabular}{ccccccc}
\hline & \multicolumn{2}{c}{ Test de LLC } & \multicolumn{2}{c}{ Test de IPS } & \multicolumn{2}{c}{ Pesaran (2004) } \\
\hline & Statistics & $P$-value & Statistics & $P$-value & Statistics & $P$-value \\
\hline L, lnPIB & $-3.0226^{* * *}(\mathrm{~b})$ & $\mathrm{I}(0)$ & $-7.2726^{* * *}(\mathrm{~b})$ & $\mathrm{I}(1)$ & $50.82^{* * *}$ & $\mathrm{I}(0)$ \\
$\operatorname{lnFBCF}$ & $-3.6183^{* * *}(\mathrm{~b})$ & $\mathrm{I}(0)$ & $-6.7457^{* * *}(\mathrm{~b})$ & $\mathrm{I}(1)$ & $6.39^{* * *}$ & $\mathrm{I}(0)$ \\
$\operatorname{lnCE}$ & $-5.2703^{* * *}(\mathrm{~b})$ & $\mathrm{I}(0)$ & $-2.8975^{* *}(\mathrm{~b})$ & $\mathrm{I}(0)$ & $22.75^{* * *}$ & $\mathrm{I}(0)$ \\
tbsp & $-3.0493^{* * *}(\mathrm{~b})$ & $\mathrm{I}(0)$ & $-3.8333^{* * *}(\mathrm{a})$ & $\mathrm{I}(0)$ & $9.95^{* * *}$ & $\mathrm{I}(0)$ \\
lnouv & $-1.7444^{* *}(\mathrm{~b})$ & $\mathrm{I}(0)$ & $-7.4021^{* * *}(\mathrm{~b})$ & $\mathrm{I}(1)$ & $6.85^{* * *}$ & $\mathrm{I}(0)$ \\
institution & $-3.3404^{* * *}(\mathrm{c})$ & $\mathrm{I}(0)$ & $-2.4170^{* * *}(\mathrm{~b})$ & $\mathrm{I}(1)$ & $-1.78^{*}$ & $\mathrm{I}(0)$ \\
interaction & $-2.9370^{* * *}$ (c) & $\mathrm{I}(0)$ & $-2.2712^{* *}(\mathrm{~b})$ & $\mathrm{I}(1)$ & $-2.37^{* *}$ & $\mathrm{I}(0)$ \\
\hline
\end{tabular}

Source: Created by the author based on data extracted from the database. ${ }^{*},{ }^{*}$ and ${ }^{\star * *}$ represent statistical significance at the $10 \%, 5 \%$ and $1 \%$ levels, respectively. The LLC stationarity test involves three equations, (a): with a trend, (b): with a constant and (c): without a constant and trend. On the other hand, the IPS test has only two equations, (a): with a trend and (b): with a constant. I(0) and I(1) correspond to integration decisions at the level and first difference, respectively. 
The stationarity table shows that all the variables are stationary in level with the LLC test with the equation admitting a constant, except for the institution variable, which is stationary in the equation without a constant and trend. Unlike the former, the IPS test has more stationary variables in the first difference than in level. There are only two variables, energy consumption and the gross primary schooling rate, that are stationary in level. The second-generation test shows that all variables are stationary in level. In view of the results of the IPS, it is necessary to check the level of cointegration.

\subsubsection{Cointegration Tests}

There are several cointegration tests conducted on the panel data. In this paper, two cointegration tests are selected. The first is the Pedroni test (1999; 2004), which is based on the same hypotheses as Kao's (1999) test and has seven statistics as in the two-group class. The first group uses four statistics. These statistics take into account common time factors and heterogeneity across countries. These statistics focus on the common autoregressive coefficients across different countries through unit root tests of the estimated residuals. The second group of statistics used in Pedroni's test consists of three statistics. These statistics are based on the averages of the different autoregressive coefficients related to the unit root tests of the residuals of each country in the panel.

In Westerlund's (2005) cointegration test, the same null hypothesis is used; however, his alternative hypothesis is broken down into two hypotheses: In the first, cointegration can occur among all variables, and in the second, cointegration occurs in only a few panels. These tests are divided into two groups: "P" and "G". The "P" tests test the null hypothesis of the absence of a cointegration relationship in the panel as a whole against the alternative hypothesis of the existence of a cointegration relationship. The "G" tests test the hypothesis of the absence of a cointegrating relationship for all individuals in the panel against the alternative hypothesis of the existence of at least one relationship at the level of an individual, for which the variables are cointegrated.

The results of the cointegration tests are presented in Table 4, Table 5.

Table 4. Pedroni test results.

\begin{tabular}{ccccccc}
\hline & \multicolumn{2}{c}{ Sans institution } & \multicolumn{2}{c}{ Institution } & \multicolumn{2}{c}{ Interaction } \\
\hline & Statistics & $p$-value & Statistics & $p$-value & Statistics & $p$-value \\
\hline Modified Variance Ratio & -5.6517 & 0.0000 & -6.3050 & 0.0000 & -6.9379 & 0.0000 \\
Modified Phillips-Perron $t$ & 2.2962 & 0.0108 & 3.5451 & 0.0002 & 4.6294 & 0.0000 \\
Phillips-Perron $t$ & -1.8903 & 0.0294 & -1.3014 & 0.0966 & -0.6012 & 0.2739 \\
Augmented Dickey-Fuller $t$ & -3.4495 & 0.0003 & -3.6586 & 0.0001 & -2.8311 & 0.0023 \\
Modified Phillips-Perron $t$ & 4,0546 & 0.0000 & 5.0894 & 0.0000 & 6.1325 & 0.0000 \\
Phillips-Perron $t$ & -4.2087 & 0.0010 & -4.8886 & 0.0000 & -4.6931 & 0.0000 \\
Augmented Dickey-Fuller $t$ & 3.1002 & 0.0000 & -3.6063 & 0.0002 & -2.7520 & 0.0030 \\
\hline
\end{tabular}

Source: Created by the author using Stata 15. 
Table 5. Westerlund test results.

\begin{tabular}{cccccccc}
\hline & \multicolumn{2}{c}{ Without institution } & \multicolumn{2}{c}{ Institution } & \multicolumn{2}{c}{ Interaction } \\
\hline & & Statistics & $p$-value & Statistics & $p$-value & Statistics & $p$-value \\
\hline Group & G & 3.4545 & 0.0003 & 3.3701 & 0.0004 & 5.7512 & 0.0000 \\
Group & $P$ & 1.5692 & 0.0583 & 1.8096 & 0.0352 & 3.1996 & 0.0007 \\
\hline
\end{tabular}

Source: Author from Stata 15.

The results of the Pedroni test show that of the seven existing statistics, only the PP Panel statistic in model 3 is not significant. However, all the statistics are significant at the 10, 5 and/or 1 levels In conclusion, cointegration relation exists.

Table 5 shows that the results of Westerlund's test shows a cointegration relation regardless of whether one is in the framework of a set or in the choice of a few panels. These results confirm the results of the previous test. Thus, the association between these variables will not lead to spurious results.

\subsubsection{GMM Estimation Results}

Estimation using the GMM can address the problems of simultaneous inverse causality bias and omitted variable bias. In particular, this method allows us to address the problem of endogeneity in a two-way relationship.

There are two variants of the dynamic panel GMM estimator: the first difference GMM estimator and the system GMM estimator. Blundell \& Bond (1998) used Monte Carlo simulations and showed that the system GMM estimator is better than the first difference GMM estimator. According to these authors, the first difference GMM estimator gives biased results in finite samples when the instruments are weak. Thus, in this paper, we prefer to use the GMM rather than the GMM in the first difference.

The results of estimating the six equations are presented in Table 6.

The table above shows that the statistics for AR(1) are all significant and those for $\mathrm{AR}(2)$ are all rejected. Therefore, we accept the presence of a residual effect for AR(1) only. Furthermore, the Hansen and Sargan tests validate the instruments used. This information allows us to validate the models and thus move on to the interpretation phase.

The coefficients of model 1 show that the energy consumption variable has a significant and positive influence on the economic growth of sub-African countries at the $10 \%$ level of significance. Thus, a $1 \%$ increase in energy consumption will lead to a $0.19 \%$ increase in economic growth in these countries, all other things being equal. The results of model 2 show that the governance quality variable, although it is not significant, accentuates economic growth. Therefore, a $1 \%$ increase in energy consumption increases economic growth by $0.428 \%$. In model 3, we reveal that energy consumption and the interaction variable are positive and significant at the respective levels of $5 \%$ and $10 \%$. On the other hand, the institution variable is now significant and has the same sign as in model 2. 
Table 6. Estimation results.

\begin{tabular}{|c|c|c|c|}
\hline & Model 1 & Model 2 & Model 3 \\
\hline \multirow[t]{2}{*}{ L.lnPIB } & 1.056 & 0.971 & 1.087 \\
\hline & $(35.94)^{* * *}$ & $(18.02)^{* * *}$ & $(17.00)^{* * *}$ \\
\hline \multirow[t]{2}{*}{$\operatorname{lnFBCF}$} & 0.012 & 0.040 & 0.019 \\
\hline & $(0.25)$ & $(0.87)$ & $(0.22)$ \\
\hline \multirow[t]{2}{*}{$\operatorname{lnCE}$} & 0.194 & 0.482 & 0.938 \\
\hline & $(1.88)^{*}$ & $(2.42)^{\star *}$ & $(2.83)^{\star *}$ \\
\hline \multirow[t]{2}{*}{ Tbsp } & -0.005 & -0.010 & -0.018 \\
\hline & $(2.02)^{\star}$ & $(2.60)^{\star \star}$ & $(4.48)^{\star \star \star}$ \\
\hline \multirow[t]{2}{*}{ lnouv } & 0.193 & 0.109 & 0.253 \\
\hline & $(2.94)^{\star * \star}$ & $(2.16)^{\star *}$ & $(2.30)^{\star *}$ \\
\hline \multirow[t]{2}{*}{ Institution } & & -0.024 & -3.526 \\
\hline & & $(0.55)$ & $(1.87)^{*}$ \\
\hline \multirow[t]{2}{*}{ Interaction } & & & 0.558 \\
\hline & & & $(1.86)^{*}$ \\
\hline \multirow[t]{2}{*}{ Constante } & -2.844 & -1.843 & -7.256 \\
\hline & $(2.72)^{\star *}$ & $(1.83)^{*}$ & $(2.40)^{\star \star}$ \\
\hline Prob_AR(1) & 0.003 & 0.014 & 0.050 \\
\hline Prob_AR(2) & 0.495 & 0.600 & 0.480 \\
\hline Prob_Sargan & 0.380 & 0.843 & 0.991 \\
\hline Prob_Hansen & 0.466 & 0.821 & 0.958 \\
\hline \multirow[t]{2}{*}{$\mathrm{N}$} & 300 & 300 & 300 \\
\hline & ${ }^{*} p<0.1$ & ${ }^{* *} p<0.05$ & ${ }^{* * *} p<0.01$ \\
\hline
\end{tabular}

Source: Author from Stata 15.

Thus, an increase in energy consumption of $1 \%$ will lead to an increase in economic growth of $0.938 \%$. The deterioration in the level of institutional quality should lead to a reduction in growth of $3.125 \%$.

Table 7 shows the results for the Granger test.

The table above shows that there is no Granger causality regardless of the type of relationship and whether the interaction variables are considered.

\subsection{Interpretation of the Results}

All these results allow us to draw two conclusions: energy consumption is a factor of economic growth, and governance quality is a catalyst for the relationship between energy consumption and economic growth.

\subsubsection{Energy Consumption: A Factor of Economic Growth}

The coefficients of energy consumption in all the models have a positive sign. These results confirm the growth hypothesis for CEMAC countries. This hypothesis 
Table 7. Granger test.

\begin{tabular}{|c|c|c|c|}
\hline Equation/Excluded & & Statistics chi2 & Probability \\
\hline \multicolumn{4}{|c|}{$\ln P I B$} \\
\hline $\ln C E$ & No Granger causality & 0.043 & 0.836 \\
\hline Institution & No Granger causality & 0.051 & 0.822 \\
\hline Interaction2 & No Granger causality & 0.077 & 0.782 \\
\hline ALL & No Granger causality & 2.337 & 0.886 \\
\hline \multicolumn{4}{|c|}{$\ln C E$} \\
\hline $\ln \mathrm{PIB}$ & No Granger causality & 0.045 & 0.833 \\
\hline Institution & No Granger causality & 0.114 & 0.736 \\
\hline Interaction 2 & No Granger causality & 0.091 & 0.763 \\
\hline ALL & No Granger causality & 1.863 & 0.932 \\
\hline \multicolumn{4}{|c|}{ institution } \\
\hline $\ln P I B$ & No Granger causality & 0.081 & 0.775 \\
\hline $\ln C E$ & No Granger causality & 0.633 & 0.426 \\
\hline Interaction2 & No Granger causality & 0.972 & 0.324 \\
\hline ALL & No Granger causality & 20.454 & 0.002 \\
\hline \multicolumn{4}{|c|}{ Interaction } \\
\hline $\ln P I B$ & No Granger causality & 0.023 & 0.880 \\
\hline $\ln F B C F$ & No Granger causality & 0.000 & 0.995 \\
\hline $\ln C E$ & No Granger causality & 0.614 & 0.433 \\
\hline Institution & No Granger causality & 2.469 & 0.116 \\
\hline ALL & No Granger causality & 24.767 & 0.000 \\
\hline
\end{tabular}

Source: Created by the author using Stata 15.

accepts the existence of a unidirectional causality from energy consumption to economic growth. In this case, policy choices should focus on energy consumption and on the nonrestrictive use of energy in the different sectors of the economy. However, conservation or restrictive policy can obviously hinder economic growth over this period. Moreover, the advocates of this hypothesis, Ghali \& El-Sakka (2004), consider energy as one of the essential factors (input) for production on the same level as labor and capital. By accepting this hypothesis, energy becomes a limiting factor of economic growth, according to Masih \& Masih (1998). Moreover, in this context, energy consumption does indeed positively affect the GDP, which suggests that in the long term, it is likely that an energy conservation program can significantly influence economic growth.

There are two possible explanations for this result. First, this result can be explained by the industrial awakening that the countries discussed in this article are experiencing. Indeed, in recent years, sub-Saharan African countries have mobilized large investment projects in the industrial sector, pushing them to consume more energy. The second reason for this result is the awareness of the 
effect of energy on socioeconomic development. In terms of development, we can rely on the MDGs ODD I and II. Since the publication of these objectives, several SSA countries have reviewed their energy policies both in terms of production and organization.

\subsubsection{The Quality of Governance: A Catalyst for the Relationship between Energy Consumption and Economic Growth}

The results of model 3 show that the coefficient of energy consumption is higher than that of the interaction variable and that both coefficients are positive and statistically significant. This result shows that energy consumption has a positive impact on economic growth and that the quality of governance accentuates this effect. This result confirms the vision of Mundial (2001). According to this author, economic development is a crucial determinant because of its effectiveness in minimizing market imperfections.

Economies with strong institutional quality are capable of implementing effective and efficient regulations that promote economic development, as shown in the World Bank (2009) report. Indeed, according to this report, poorly managed companies in sub-Saharan African countries are inefficient and incur significant technical and commercial losses that reduce their ability to finance new investments. The application of below-cost tariffs exacerbates the difficulties of all energy companies, regardless of whether they are public and private. It is important to strengthen governance to ensure that energy promotes equitable economic development. Governance is important at all levels of the sector: government, public agencies, businesses and consumers. Given that the energy sector will remain in the hands of state-owned enterprises in the coming years in many SSA countries, it is particularly important to improve their governance and strengthen their overall performance. For many major hydrocarbon exporters, improved management of the sector can help stimulate sustainable economic growth that would benefit all.

\section{Conclusion and Policy Implications}

The objective of this paper was to analyze the role of governance quality on the relationship between economic growth and energy consumption in a panel of twenty (20) sub-Saharan African (SSA) countries over a period from 1996 to 2017. Techniques such as the generalized method of moments (GMM) in dynamics and the Granger test were utilized. The results of the estimations show that energy consumption is an essential factor in the economic growth of SSA countries and the quality of governance is a catalyst of this relationship. The policy implications of these results are elaborated.

These implications have two economic policy implications.

- The introduction of growth policies in the sub-Sahara region must be accompanied by an energy policy. This recommendation is not new, but the lack of this policy may explain the difficulty of expanding SSA's economies. Indeed, in African countries, energy is still a scarce commodity, if not insuf- 
ficient in view of important development needs. The potential being enormous in some countries such as the Democratic Republic of Congo, Nigeria and South Africa, African countries should give priority to integrating projects in order to develop clean energy.

- Governance policies in the energy sector must be strengthened in SSA countries. This recommendation is justified by the fact that governance systems in these countries are still in their infancy and not yet fully satisfactory. However, the application of governance standards contributes to improved performance in the various energy sectors, which has implications for the functioning of the economy in terms of productive and economic efficiency. Thus this reduces the cost of energy and promotes economic growth, and the implementation of governance standards can increase revenues in various energy sectors, which can be reflected in the level of operation (productive and economic efficiency) and thus reduce the cost of energy and promote economic growth.

\section{Conflicts of Interest}

The authors declare no conflicts of interest regarding the publication of this paper.

\section{References}

Acemoglu, D., Johnson, S., \& Robinson, J. A. (2001). The Colonial Origins of Comparative Development: An Empirical Investigation. American Economic Review, 91, 1369-1401. https://doi.org/10.1257/aer.91.5.1369

Acemoglu, D., Johnson, S., Robinson, J., \& Yared, P. (2008). Income and Democracy. American Economic Review, 98, 808-842. https://doi.org/10.1257/aer.98.3.808

Adams, S., Klobodu, E. K. M., Opokub, E. E. O. (2016). Energy Consumption, Political Regime and Economic Growth in Sub-Saharan Africa. Energy Policy, 96, 36-44. https://doi.org/10.1016/j.enpol.2016.05.029

Bai, J., \& Ng, S. (2004). A Panic Attack on Unit Roots and Cointegration. Econometrica, 72, 1127-1177.

Barro, R. (1990). Government Spending in a Simple Model of Economic Growth. Journal of Political Economy, 98, 103-125. https://doi.org/10.1086/261726

Bass, A. (2019). Do Institutional Quality and Oil Prices Matter for Economic Growth in Russia: An Empirical Study. International Journal of Energy Economics and Policy, 9, 76-83.

Batila, N. K. (2018). Effets de l'annulation de la dette et de la qualité des institutions sur la croissance économique dans les pays de la CEMAC. Annales de l'Universite Marien Ngouabi Sciences Economiques et de Gestion, 18, 101-114.

van der Bergh, J. C. (2001). Ecological Economics: Themes, Approaches, and Differences with Environmental Economics. Regional Environmental Change, 2, 13-23. https://doi.org/10.1007/s101130000020

Bhattacharya, M., \& Bhattacharya, S. N. (2014). Economic Growth and Energy Consumption Nexus in Developing World: The Case of China and India. Journal of Applied Economics \& Business Research, 4, 150-167. 
Blundell, R., \& Bond, S. (1998). Initial Conditions and Moment Restrictions in Dynamic Panel Data Models. Journal of Econometrics, 87, 115-143. https://doi.org/10.1016/S0304-4076(98)00009-8

Breitung, J. (2000). The Local Power of Some Unit Root Tests for Panel Data. In B. H. Baltagi, T. B. Fomby, \& R. Carter Hill (Eds.), Nonstationary Panels, Panel Cointegration, and Dynamic Panels (pp. 161-177). Bingley: Emerald Group Publishing Limited. https://doi.org/10.1016/S0731-9053(00)15006-6

Choi, I. (2001). Unit Root Tests for Panel Data. Journal of International Money and Finance, 20, 249-272. https://doi.org/10.1016/S0261-5606(00)00048-6

Choi, I. (2002). Combination Unit Root Tests for Cross-Sectionally Correlated Panels. Hong Kong University of Science and Technology, Mimeo.

Edame, G. E., \& Okoi, O. B. (2015). Energy Consumption, Institutional Quality and the Performance of the Manufacturing Sector in Nigeria (1999-2013). International Journal of Energy Economics and Policy, 5, 801-804.

Emmanuel, N., \& Ebi, B. O. (2013). Institutional Quality, Petroleum Resources and Economic Growth: A Difference in Differences Approach Using Nigeria, Brazil and Canada. International Journal of Humanities and Social Science, 3, 198-206.

Ghali, K. H., \& El-Sakka, M. I. (2004). Energy Use and Output Growth in Canada: A Multivariate Cointegration Analysis. Energy Economics, 26, 225-238. https://doi.org/10.1016/S0140-9883(03)00056-2

Hadri, K. (2000). Testing for Stationarity in Heterogeneous Panel Data. The Econometrics Journal, 3, 148-161. https://doi.org/10.1111/1368-423X.00043

Hall, R. E., \& Jones, C. I. (1999). Why do Some Countries Produce So Much More Output Per Worker than Others? The Quarterly Journal of Economics, 114, 83-116. https://doi.org/10.1162/003355399555954

IEA (2014).World Energy Outlook 2014. https://www.iea.org/reports/world-energy-outlook-2014

Im, K. S., Pesaran, M. H., \& Shin, Y. (2003). Testing for Unit Roots in Heterogeneous Panels. Journal of Econometrics, 115, 53-74. https://doi.org/10.1016/S0304-4076(03)00092-7

Jumbe, C. B. (2004). Cointegration and Causality between Electricity Consumption and GDP: Empirical Evidence from Malawi. Energy Economics, 26, 61-68. https://doi.org/10.1016/S0140-9883(03)00058-6

Kane, C. S. (2009). Demande d'énergie et croissance économique dans les pays de l'UEMOA. Revue Africaine de l'Intégration, 3, 1-33.

Kao, C. (1999). Spurious Regression and Residual-Based Tests for Cointegration in Panel Data. Journal of Econometrics, 90, 1-44. https://doi.org/10.1016/S0304-4076(98)00023-2

Kaufmann, D., Kraay, A., \& Zoido-Lobaton, P. (1999). Governance Matters. Policy Research Working Paper.

Kilishi, A. A., Mobolaji, H. I., Yaru, M. A., \& Yakubu, A. T. (2013). Institutions and Economic Performance in Sub-Saharan Africa: A Dynamic Panel Data Analysis. Journal of African Development, 15, 91-119.

Kouika, J. R. F. K., Ngassa, T. C., \& Ndinga, M. M. A. (2018). The Effects of Regulatory Quality on the Pro-Cyclicality of Fiscal Policy in Countries in the Central African Economic and Monetary Community (CA EMC). Modern Economy, 9, 1228-1246. https://doi.org/10.4236/me.2018.97080

Kraft, J., \& Kraft, A. (1978). On the Relationship between Energy and GNP. Journal of 
Energy and Development, 3, 401-403.

Lékana, H. C. (2018a). Effets de la consommation d'énergie sur la croissance économique dans les pays membre de la Communauté Economique et Monétaire d'Afrique Centrale (CEMAC) (187 p). Thèse de doctorat, Université Marien Ngouabi, Soutenue le 09 Aout 2018.

Lékana, H. C. (2018b). Relation entre la consommation d'énergie et la croissance économique dans les pays de la CEMAC. Annales de l'universite marien ngouabi sciences economiques et de gestion, 18, 57-72.

Levin, A., Lin, C. F., \& Chu, C. S. J. (2002). Unit Root Tests in Panel Data: Asymptotic and Finite Sample Properties. Journal of Econometrics, 108, 1-24.

https://doi.org/10.1016/S0304-4076(01)00098-7

Loubelo, D. B. (2018). Corruption et investissement privé dans les pays de la Communauté économique et monétaire de l'Afrique centrale (CEMAC). Annales de l'Universite Marien Ngouabi Sciences Économiques et de Gestion, 18, 238-252.

Lucas, R. (1988). On the Mechanics of Economic Development. Journal of Monetary Economics, 22, 3-42. https://doi.org/10.1016/0304-3932(88)90168-7

Maddala, G. S., \& Wu, S. (1999). A Comparative Study of Unit Root Tests with Panel Data and a New Simple Test. Oxford Bulletin of Economics and Statistics, 61, 631-652. https://doi.org/10.4236/me.2018.97080

Mankiw, N. G., Romer, D., \& Weil, D. (1992). A Contribution to the Empirics of Economic Growth. The Quarterly Journal of Economics, 107, 407-437.

https://doi.org/10.2307/2118477

Masih, A. M., \& Masih, R. (1998). A Multivariate Cointegrated Modelling Approach in Testing Temporal Causality between Energy Consumption, Real Income and Prices with an Application to Two Asian LDCS. Applied Economics, 30, 1287-1298. https://doi.org/10.1080/000368498324904

Moon, H. R., \& Perron, B. (2004).Testing for a Unit Root in Panels with Dynamic Factors. Journal of Econometrics, 122, 81-126. https://doi.org/10.1016/j.jeconom.2003.10.020

Mundial, B. (2001). World Development Report 2002: Building Institutions for Markets. Banco No. 2196, Washington DC: World Bank.

North, D. C. (1990). Institutions, Institutional Change, and Economic Performance. Cambridge: Cambridge University Press. https://doi.org/10.1017/CBO9780511808678

Ogundipe, A. A., Akinyemi, O., \& Ogundipe, O. M. (2016). Electricity Consumption and Economic Development in Nigeria. International Journal of Energy Economics and Policy, 6, 134-143.

Okiemy, M. (2018). Effets de la dette sur la cyclicité de la politique budgétaire: cas de la CEMAC. Annales de I'Universite Marien Ngouabi Sciences Economiques et de Gestion, 18, 358-369.

Pedroni, P. (1999). Critical Values for Cointegration Tests in Heterogeneous Panels with Multiple Regressors. Oxford Bulletin of Economics and Statistics, 61, 653-670. https://doi.org/10.1111/1468-0084.61.s1.14

Pedroni, P. (2004). Panel Cointegration: Asymptotic and Finite Sample Properties of Pooled Time Series Tests with an Application to the PPP Hypothesis. Econometric Theory, 20, 597-625. https://doi.org/10.1017/S0266466604203073

Percebois, J., \& Hansen, J.-P. (2011). Energie. De Boeck Université.

Pesaran, M. H. (2004). General Diagnostic Tests for Cross Section Dependence in Panels. CESifo Working Papers No.1233. 
Saidi, H., El Montasser, G., \& Ajmi, N. (2018). Renewable Energy, Quality of Institutions and Economic Growth in MENA Countries: A Panel Cointegration Approach. MPRA Paper No. 84055.

Shafiei, S., Salim, R. A., \& Cabalu, H. (2013). The Nexus between Energy Consumption and Economic Growth in OECD Countries: A Decomposition Analysis. Perth: School of Economics \& Finance, Curtin Business School, Curtin University.

Simon, O. (2010). Mesure des Performances économiques et du progrès Social: les Conclusions de la Commission Stiglitz-Sen-Fitoussi. Économie \& Prévision, 193, 121-129.

Sobrinho, N., \& Thakoor, V. (2019). Plus de sable que de carburant. Finances \& Développement.

https://www.imf.org/external/pubs/ft/fandd/fre/2019/09/pdf/tackling-corruption-in-su b-saharan-africa-sobrinho.pdf

Stern, D. I. (2012). Modeling International Trends in Energy Efficiency. Energy Economics, 34, 2200-2208. https://doi.org/10.1016/j.eneco.2012.03.009

Stiglitz, J. (1974). Growth with Exhaustible Natural Resources: Efficient and Optimal Growth Paths. The Review of Economic Studies, 41, 123-137. https://doi.org/10.2307/2296377

Streimikiene, D., \& Kasperowicz, R. (2016). Review of Economic Growth and Energy Consumption: A Panel Cointegration Analysis for EU Countries. Renewable and Sustainable Energy Reviews, 59, 1545-1549. https://doi.org/10.1016/j.rser.2016.01.041

UNDP (2015). Global Sustainable Development Report 2015 Edition. https://sustainabledevelopment.un.org/content/documents/1758GSDR\%202015\%20Ad vance\%20Unedited\%20Version.pdf

Westerlund, J. (2005). New Simple Tests for Panel Cointegration. Econometric Reviews, 24, 297-316. https://doi.org/10.1080/07474930500243019

World Bank (2009). Groupe Banque Mondiale Strategie énergetique Sectecorielle Synthese. http://www.reseau-cicle.org/wp-content/uploads/riaed/pdf/Banque mondiale Strategi e energetique sectorielle 1009.pdf 